\title{
Comics in the Classroom: Something to Be Taken Seriously
}

\author{
Steven Graham \\ Khon Kaen University International College, Thailand
}

\begin{abstract}
Children enjoy reading comics, so it makes perfect sense to use such a resource to enhance English-language learning. Using dialogues created for audiovisual materials that reflect curriculum requirements of English language teaching and learning, it is possible to create supplementary gap-fill activity cartoons to recycle content in line with a required schema of works.
\end{abstract}

This paper recounts an ongoing longitudinal project that is in the process of designing a comics series based on the curriculum requirements for the first six years of English language basic education (primary) in Thailand. The dialogues are based on the language found in end-of-year examination preparatory books (O Net and N Net) and input into an Internet-based comic-making application, www.makebeliefscomix.com. Early indications are that students benefit from the recycling of language and the introduction in the early years of activities such as gap-fill. Moreover, students have been able to practice writing as an additional activity.

Thailand has an archaic education system that has an emphasis on basic literacy and rote memorisation, resulting in Thailand's TOEFL scores for university entrance overseas ranking amongst the lowest in Asia (Kurlantzick, 2010). Academic expectations in Thailand have been low for many years; students rarely fail English subjects even though their English skills are weak. The idea of maintaining high standards and allowing students to fail (Andrade, 2010) is uncommon and has been reflected in the lacklustre approach to academic support for the teaching profession. Moreover, internal quality control mechanisms are lacking (Graham, 2009a), resulting in educational institutions becoming "robot factories" designed to maintain the existing class boundaries within society (Yatvin, 2010). What is needed are communicative materials that can be administered in the classroom in a learner-centred way.

The vast majority of primary school teachers of English in Thailand did not major in English language teaching and so, by their own admission (Mackenzie, 2002, 2004), do not possess the English language skills or communicative teaching style to teach in a learner-centred way in accordance with the 1999 Education Act (Foley, 2005). Thailand shares similarities with countries like Iran, in that there is a lack of personal English language skills and poor social conditions for these teachers (Namaghi, 2010). 
Ujiie and Krashen (1996) explain that reading comics does not inhibit other types of reading and that it in fact facilitates heavier reading, which in time could lead to students becoming better readers (Krashen, 1993). Unlike film, comics have a "permanent, visual component" (Williams, 1995, p. 2), and by mixing comics with "dialogue, which is permanent, but not visual" (p. 3), it is possible to create an exciting new set of English language teaching materials suitable for use by primary school students. The tasks they perform are designed to motivate students to use language for specific aims (Van den Branden, 2009) where vocabulary is predominantly learned by focusing on form for better retention (Laufer, 2005, as cited in Keating, 2008, p. 381).

The process detailed in this paper started as a teacher training project and progressed to making dialogues from national examinations and adapting them to scenes for a set of DVDs (Smooth Transitions) following the primary school curriculum. After these initial tasks were completed, the dialogues were then used with speech recognition software and in the making of a series of comics.

\section{Smooth Transitions}

The concept behind Smooth Transitions is to have a communicative activity or activities that could be added on to the existing lessons that primary school teachers are teaching as a transitional stage from teacher-centred to learner-centred teaching, a type of continuous improvement (Anderson \& Kumari, 2009) on what is already being taught in the classroom. It is impossible to expect these teachers of English, especially those in rural areas who have not been trained in how to teach communicative activities in a learner-centred way, to move from zero to hero overnight. However, twelve years after the 1999 Education Act, it might be expected that more progress would have been made than what can be seen at this time.

Initial training for the three primary school teachers involved in the Smooth Transitions project took approximately two hours and involved demonstrations on how to use an audio CD of dialogues adapted from $\mathrm{O}$ Net / N Net testing books and the use of sets of donated flashcards. Why this project succeeded when others failed was the support after training had taken place. Teachers were observed and videoed one week and then there was a reflection period before feedback was offered the following week. During the period of reflection, teachers were encouraged to watch themselves and their colleagues on the DVDs that were provided for them. Graham (2009b) gives a more detailed account of the project, which continued for more than one year.

From these feedback sessions, the idea emerged from a teacher that DVDs be made to further facilitate the learning experience of her students. They had been looking at a blank television screen when listening to the dialogues that were played on the DVD player that was connected to the television. She also asked for subtitles in English, which confirms the thinking of Stillwell (2010) that supporting listening activities with subtitles makes sense. This idea led to the production of a set of DVDs that contained dialogues with subtitles as requested by the teacher, using the same series of O Net / N Net test books.

Two central characters, Bank and Noi, played by the author's children, appear throughout the whole series. Students watch and listen to a selected portion of the DVD several times before the teacher instructs them to repeat what was said. This only takes place after the students understand what has been said, which involves the teacher looking back at the previous part of the lesson and confirming what the dialogue means, using the students' L1. The boys follow Bank and the girls follow Noi. Once the teacher is satisfied that the section of dialogue has 
been understood, all of the students are encouraged to come to the front of the class to act as Bank and Noi. The teacher starts and pauses the DVD to make bite-size segments to avoid overloading the students. A more detailed account of how to use the DVDs is described by Graham (2010).

This type of role-play plays an important part in students' character building and life skills if it is implemented correctly. In explanation, Hayati (2006) states how it is fun and motivating for all students as they try to express themselves in another language. This can been seen in Figure 1 below. If planned well, role-plays are not monotonous and move away from the normal memorisation and grammar that are all too common in Thailand's English language

classrooms. Students cooperate with each other, build trust with their peers and their teachers, and most important of all, learn not to be afraid of making mistakes. Their confidence and selfesteem increase.

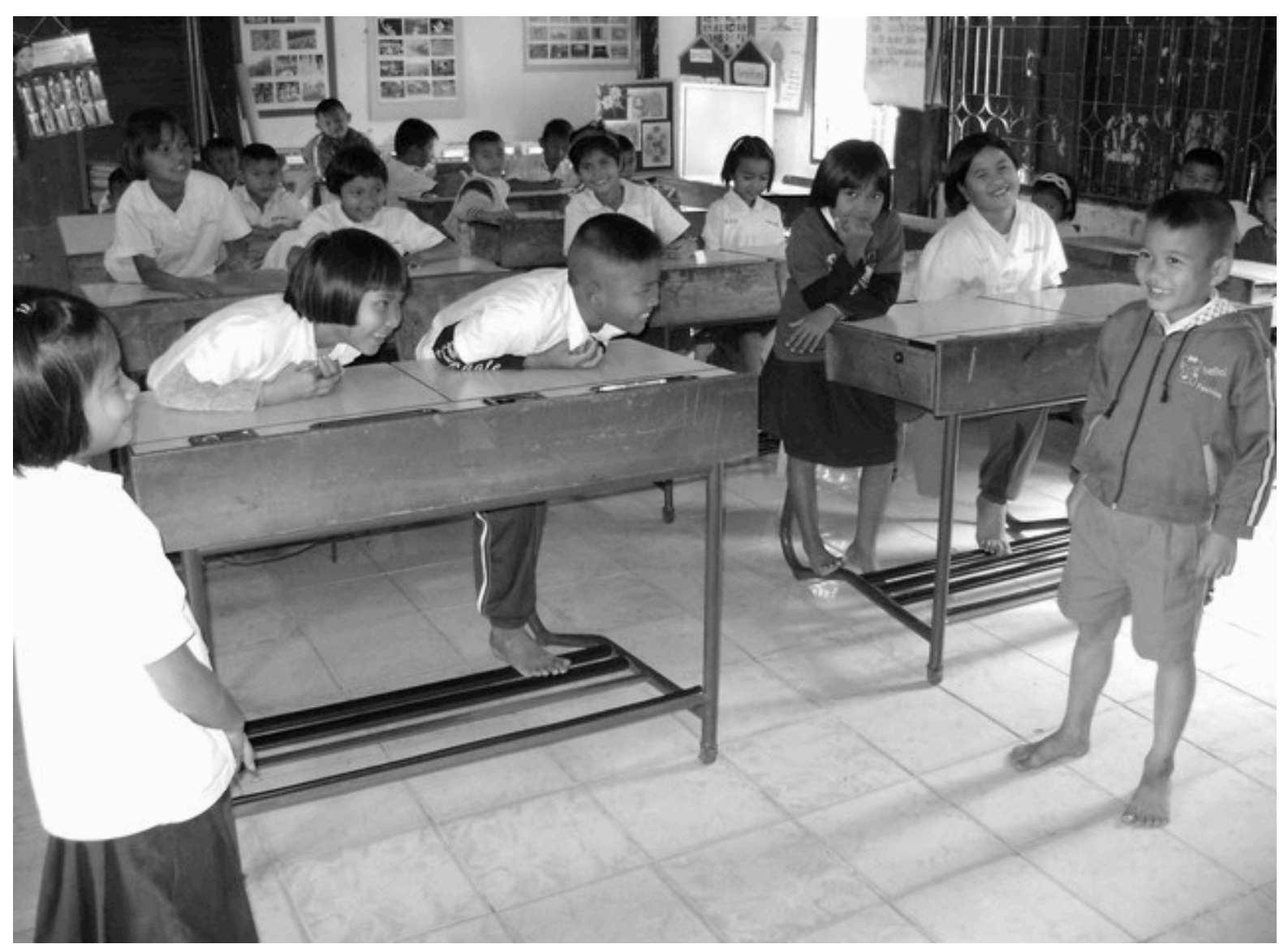

Figure 1. Two second-grade students from Bantatprachanukoon School in Ban Phue District, Udon Thani Province in Thailand take their turns at role-playing the characters Bank and Noi, encouraged by the rest of the class.

\section{SpeaKIT Voice Recognition}

By using the dialogues that had been created for the Smooth Transitions DVDs, it was possible to create exercises in the SpeaKIT voice recognition software program (http://www.teachingmachine.com/) to enable students to practice their reading and pronunciation skills. 
SpeaKIT has state-of-the-art technology driven by data algorithms (Marchand, Adsett \& Damper, 2009). It is classified as independent Automatic Speech Recognition (ASR) in that the program sets the standards as to what is acceptable pronunciation, meaning that it does not adapt to the speaker. A project conducted by Li and Topolewski (2002) shows how dependent ASR works when designing language learning simulations, and Pavlichev (2002) explains that if the program adapts to the user, the student would not benefit in the same way.

The SpeaKIT program, which contains a large vocabulary, offers continuous speech recognition (Lotto \& Holt, 2011) easily capable of dealing with the different types of English that can be produced (Franco, Bratt, Rossier, Gadde, Shriberg, Abrash, \& Precoda, 2010), resulting in uniformity when it comes to judgments in oral assessments (Kim, 2009).

Students are required to watch a segment of the Smooth Transitions DVD. When they are ready, they start the SpeaKIT speech recognition software that shows the dialogues on the computer screen. The program highlights what has to be said and the students speak into the microphone. When there is an error, the students have up to four attempts at self-correction before SpeaKIT advances to the next phrase. A more detailed account of how SpeaKIT works in conjunction with Smooth Transitions is contained in Graham (2011).

Although Chambers (2003) concluded from her research that computer-mediated communications (CMC) are not culturally or morally neutral, because SpeaKIT is contentneutral, it allows teachers to write their own lesson material, making it as culturally or morally neutral as they wish.

Students are encouraged to try out the speech recognition software in whatever holistic strategy they wish (Levy, 2009) in order for them to become more confident as readers and speakers as well as to practice their computer skills. Research is taking place at this time to look at the advantages of this type of activity and how it benefits the students and teachers that use it.

\section{Comics}

The website MakeBeliefsComix (http://www.makebeliefscomix.com/) was used to create gapfill comics based on the Smooth Transitions dialogues that were used for the DVDs and the SpeaKIT speech recognition software program. The website allows teachers to select characters and create cartoon comics with speech bubbles. Keeping to the central characters Bank and Noi was easy, as the same two characters were used throughout. Even though the cartoon characters in the comics do not look like the real life characters Bank and Noi in the Smooth Transitions DVDs, students are still able to refer to the cartoon characters as Bank and Noi (El Refaie, 2009), so that when they are completing the comic activities, the comics act as visual steps in the process of transforming the text into a mental model (Glenberg, Kruley, \& Langston, 1994).

Students complete the comic activities in conjunction with the Smooth Transitions DVDs. After they watch segments of a DVD several times, the teacher plays one segment again and pauses the DVD. Students have three pieces of paper. The first two are the gap-fill comic to be completed and a list of missing words (Appendix A). The last is a paper with a series of three lines to help students with a writing activity at the end of the exercise. The lined paper is set out in such a way as to help the first grades form the letters correctly, especially the capital letters in relation to lowercase letters. 

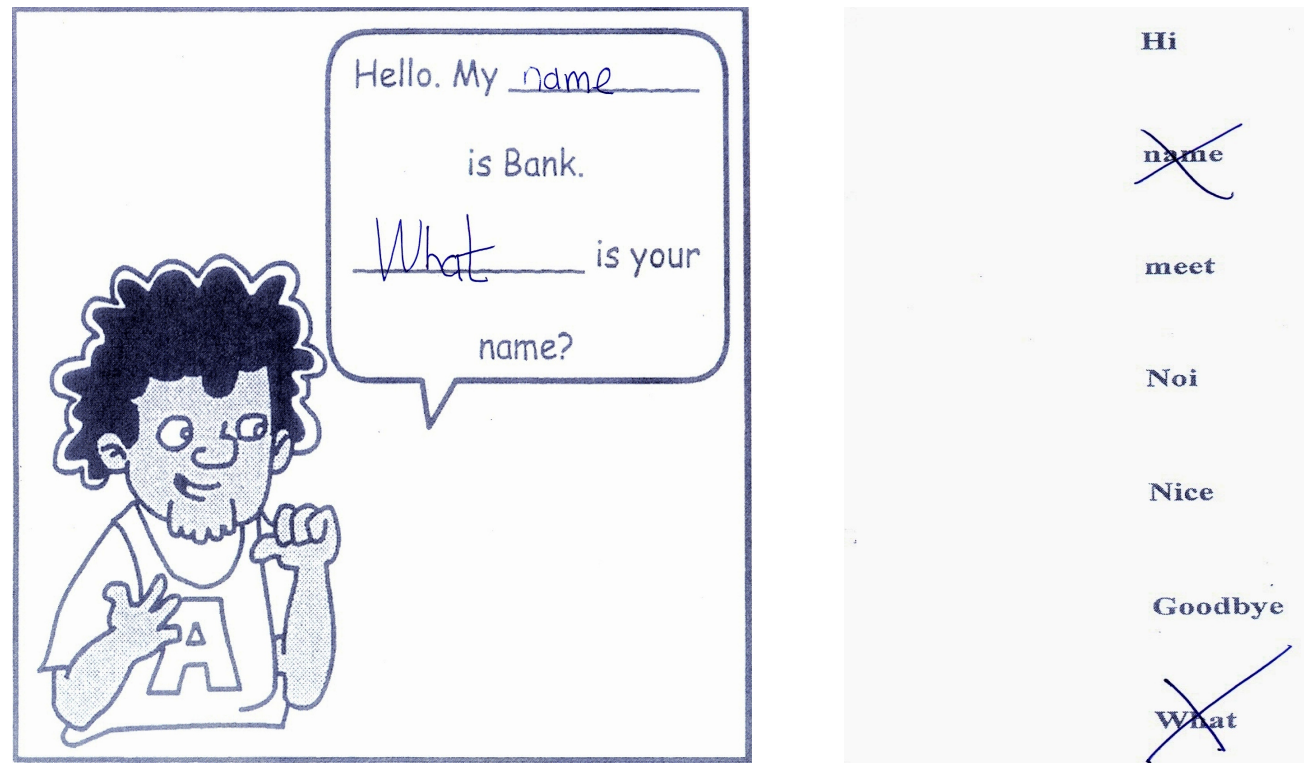

Figure 2. As students write the missing word in the gap, they cross off the word from their list of missing words.

When the DVD is paused, students look at the subtitles and work out which word is missing from the speech bubble in the comic strip. They look for the word on the list of missing words, cross it off, and then enter the missing word into the gap in the comic strip bubble, as shown in Figure 2. This is repeated until all the DVD segments are completed. Finally, students copy their completed texts onto the lined paper and the teacher gives individual feedback to students. Students are able to work in groups, allowing teachers of large classes to spend more time with individual students, maximising the opportunity afforded due to changing classroom dynamics and contexts (Blatchford, Bassett, \& Brown, 2008) to manage their contact with students as effectively as possible.

The writing component following the gap-fill comic activity gives teachers the opportunity to give both written and spoken corrective feedback (Hartshorn, Evans, Merrill, Sudweeks, StrongKrause, \& Anderson, 2010) to students on an individual basis, which although timeconsuming, proved very effective in producing improved written work and motivating the students. This is especially important for young learners, as writing skills need the most scaffolding (Senior, 2011).

The use of L1 in the classroom is a subject of particular academic interest; however, this project relies upon the students understanding what the English dialogues mean in Thai and how to complete the tasks they are given. There is a strategic use of $L 1$ as a planned aid to achieve the language learning goals (Littlewood \& Yu, 2009). The teachers speak a considerable amount of Thai during the presentation stage, less during the practice stage, and even less at the production stage of their lessons. Throughout this time, students produce the target language; however, they are always permitted to ask questions in the L1 to confirm any matter not at first understood (Krashen, 2006). The L1 of the teachers and students is used as a free and useful teaching resource at their disposal (Ibarra Hidalgo, 2010), resulting in students understanding what they have to learn and how they have to learn, thus increasing motivation (Gross, 2004).

Gap-fill activities have had a resurgence in popularity due to their use with CD-ROMS and web-based activities, leaving behind some of the stigma that they had attracted due to their 
association with the grammar-translation method (Hughes, 2006). By using comics in context (O'Dwyer, 2010), students benefit as the comics enable the formation of their schema (Jones, 2010), recycle their text-level comprehension (Yamashita, 2003) and if used for testing purposes, improve their global-level comprehension and higher order skills, cohesion, and coherence (Bachman, 1982).

These gap-fill activities allow for confirmation of vocabulary that is taught in lexical sets following the Smooth Transitions DVDs, without the danger of interference between related words (Nation, 2000), as items are presented at different times in different contexts and then confirmed by the comics. In addition, it is important to note that the gap-fill activity does not have to be for just vocabulary; this activity can also be used for grammar as well. It is up to the teacher to decide what areas to concentrate on and when to implement the gap-fill activity.

\section{Conclusion}

In gap-fill comics, the text is presented in easy-to-understand speech bubbles (Kew \& White, 2009), allowing young language beginners the opportunity to read English in an enjoyable way. Liu's (2004) study suggests that reading comprehension in low-level students is greatly facilitated when the comic strip repeats information from a previous text. It is too early to tell whether the reading comprehension of the students has been improved by the recycling of the Smooth Transitions DVD dialogues in the comics; however, early indications are positive and show students also enjoy completing the comic activities.

Having used audiovisual equipment as well as speech recognition software, there was a danger that students would not readily accept the more mundane pen and paper activities (Rajaratnam, 1988) such as the writing that follows the comic gap-fill activities; however, this was not the case. One of the first grade classes that trialled the comics and writing activities was very enthusiastic about writing, as they had not even covered the alphabet at that time. Under the guidance of their teacher, they were able to copy the text from their comic strip to the writing paper and understand the concepts of capital letters and full-stops.

By completing these gap-fill comic tasks, students are stimulated to recycle what they have learned and make form, meaning, and function relationships as they use the English language for a specific goal (Van den Branden, 2009). Keating (2008) supports claims by Laufer (2005) that by using a focus-on-form component of vocabulary instruction, word learning and retention are increased.

Future areas to be investigated as part of this study are the use of word order exercises, where students rearrange the word order in the speech bubbles of the cartoons, instead of filling in gaps. Another future enquiry by this project will be the area of voice recognition in relation to the comics dialogues. SpeaKIT has the facility to produce gap-fill activities, which allows dialogues used for the comics activities to be input into the program, in turn allowing students to read the text and put the correct word into the gap. Students will also have the opportunity to design their own comics with the MakeBeliefsComix website, with the more advanced students using their own dialogues. There has also been experimentation into the use of gapfill comics to test students, as using the same gap-fill activities to test represents testing in the manner in which students have been taught (Shaul, 2010). Data has been collected and will be analysed at a later date.

The only way that Thailand can improve on its current weakness in English language skills is to build on innovation, such as with the use of Smooth Transitions DVDs and SpeaKIT voice 
recognition software. The use of comics, in conjunction with well-planned continuous teaching in the higher grades which exposes students to authentic communicative activities in the target language at every available opportunity (Marinova-Todd, Marshall, \& Snow, 2000). Once students have the confidence to use English in the classroom, they need to transfer their skills and use them outside (Woodrow, 2006), which does occur in the capital, Bangkok, but unfortunately not in rural environments in Thailand.

The main area of concern for educationalists and parents in Thailand is that innovative visions and imagination may come into conflict with the need to prepare student teachers for schools as they really exist (Kahne \& Westheimer, 2000); however, this paper outlines a model for Thailand which can also be easily adapted for other Asian and non-Asian countries.

\section{Author Note}

Steven Graham, Khon Kaen University International College, Thailand.

Correspondence concerning this article should be emailed to Steven Graham at: steven@kku.ac.th 


\section{References}

Anderson, S., \& Kumari, R. (2009). Continuous improvement in schools: Understanding the practice. International Journal of Educational Development, 29(3), 281-292. http://dx.doi.org/10.1016/j.ijedudev.2008.02.006

Andrade, M. S. (2010). Increasing accountability: Faculty perspectives on the English language competence of nonnative English speakers. Journal of Studies in International Education, 14(3), 221-239. http://dx.doi.org/10.1177/1028315308331295

Bachman, L. F. (1982). The trait structure of cloze test scores. TESOL Quarterly, 16(1), 61-70. Blatchford, P., Bassett, P., \& Brown, P. (2008). Do low attaining and younger students benefit most from small classes? Results from a systematic observation study of class size effects on pupil classroom engagement and teacher pupil interaction. Retrieved from http://www.classsizeresearch.org.uk/aera\%2008\%20paper.pdf

Chambers, E. (2003). Cultural imperialism or plurism? Cross-cultural electronic teaching in the humanities. Arts and Humanities in Higher Education, 2(3), 249-264. http://dx.doi.org/10.1177/14740222030023003

El Refaie, E. (2009). Multiliteracies: How readers interpret political cartoons. Visual Communication, 8(2), 181-205. http://dx.doi.org/10.1177/1470357209102113

Foley, J. A. (2005). English in ... Thailand. RELC Journal, 36(2), 223-234. http://dx.doi.org/10.1177/0033688205055578

Franco, H., Bratt, H., Rossier, R., Gadde, V. R., Shriberg, E., Abrash, V., Precoda, K. (2010). EduSpeak: A speech recognition and pronunciation scoring toolkit for computer-aided language learning applications. Language Testing, 27(3), 401-418. http://dx.doi.org/10.1177/0265532210364408

Glenburg, A. M., Kruley, P., \& Langston, W. E. (1994). Analogical processes in comprehension: Simulation of a mental model. In M. A. Gernsbacher (Ed.), Handbook of psycholinguistics (pp. 609-640). San Diego, CA: Academic.

Graham, S. (2009a). External quality assurance: What effect does it have on the EFL Classroom? IATEFL Testing and Evaluation and Assessment Special Interest Group, March 2009, 17 29.

Graham, S. (2009b). From the bottom up: A case study of teacher training for primary school teachers of English in a Thai School in north eastern Thailand. English Language Teacher Education and Development, 12, 31-43.

Graham, S. (2010). EIL in the primary classroom: Exploration and innovation using DVDs for communication. Journal of Asia Pacific Studies, 1(3), 506-523.

Graham, S. (2011, January). Local to global: Primary school English audio-visual speech recognition. Paper presented at the 31st Thailand TESOL International Conference, Chiang Mai, Thailand.

Gross, S. (2004). Nothing motivates like success. The International Journal of Foreign Language Teaching, 1(1), 41-42.

Hartshorn, K. J., Evans, N. W., Merrill, P. F., Subweeks, R. R., Strong-Krause, D., \& Anderson, N. J. (2010). Effects of dynamic corrective feedback on ESL writing accuracy. TESOL Quarterly, 44(1), 84-109. http://dx.doi.org/10.5054/tq.2010.213781

Hayati, M. (2006). Take 2, Act 1: Feeding two birds with one scone! The role of role-playing in teaching English. Arts and Humanities in Higher Education, 5(2), 209-219. http://dx.doi.org/10.1177/1474022206060000

Hughes, J. (2006, September). Over to you ... Gap-fills. English Teaching Professional, pp. 8-9. Ibarra Hidalgo, S. V. (2010, February). Keep your friends close. IATEFL Voices, pp. 4-5.

Jones, E. (2010). The use of comic book style reading material in an EFL extensive reading program: A look at the changes in attitude and motivation to read in English in a Japanese university. Language Education in Asia, 1(1), 228-241. 
Kahne, J., \& Westheimer, J. (2000). A pedagogy of collective action and reflection: Preparing teachers for collective school leadership. Journal of Teacher Education, 51(5), 372-383. http://dx.doi.org/10.1177/0022487100051005005

Keating, G. D. (2008). Task effectiveness and word learning in a second language: The involvement load hypothesis on trial. Language Teaching Research, 12(3), 365-386. http://dx.doi.org/10.1177/1362168808089922

Kew, C., \& White, A. (2009). Think outside the bubble by adding comic books to your language curriculum. The Language Educator, 4(4), 49-53.

Kim, Y-H. (2009). An investigation into native and non-native teachers' judgments of oral English performance: A mixed methods approach. Language Testing, 26(2), 187-217. http://dx.doi.org/10.1177/0265532208101010

Krashen, S. D. (1993). The power of reading. Englewood, CA: Libraries Unlimited.

Krashen, S. D. (2006). Is first language use in the classroom good or bad? It depends. The International Journal of Foreign Language Teaching, 2(1), 9.

Kurlantzick, J. (2010, June). The end of brand Thailand. Newsweek. Retrieved from http://www.newsweek.com/2010/06/04/the-end-of-brand-thailand.html

Laufer, B. (2005). Focus on form in second language vocabulary learning. EUROSLA Yearbook, $5,223-250$.

Levy, R. (2009). 'You have to understand words . . . but not read them': Young children becoming readers in a digital age. Journal of Research in Reading, 32(1), 75-91. http://dx.doi.org/10.1111/j.1467-9817.2008.01382.x

Li, R-C., \& Topolewski, D. (2002). Zip \& Terry: A new attempt at designing language learning simulations. Simulation \& Gaming, 33(2), 181-186. http://dx.doi.org/10.1177/1046878102332006

Littlewood, W., \& Yu, B. (2011). First language and target language in the foreign language classroom. Language Teaching, 44(1), 64-77. http://dx.doi.org/10.1017/S0261444809990310

Liu, J. (2004). Effects of comic strips on L2 learners' reading comprehension. TESOL Quarterly, $38(2), 225-243$.

Lotto, A., \& Holt, L. (2011). Psychology of auditory perception. Wiley Interdisciplinary Reviews: Cognitive Science, 2. http://dx.doi.org/10.1002/wcs.123

Mackenzie, A. S. (2002). EFL curriculum reform in Thailand. Paper presented at the Curriculum Innovation, Testing and Evaluation: Proceedings of the 1st Annual KALT Pan-Sig Conference, Kyoto, Japan.

Mackenzie, A. S. (2004). Small steps in English language teacher development in Surin: Step one. Retrieved from http://vensite.org/main/images/Small_Steps_Mackenzie.pdf

Marchand, Y., Adsett, C. R., \& Damper, R. I. (2009). Automatic syllabification in English: A comparison of different algorithms. Language and Speech, 52(1), 1-27. http://dx.doi.org/10.1177/0023830908099881

Marinova-Todd, S. H., Marshall, D. B., \& Snow, C. E. (2000). Three misconceptions about age and L2 learning. TESOL Quarterly, 34(1), 9-34.

Namaghi, S. A. O. (2010). Parameters of language teaching in the context of high schools of Iran: A data-first approach. Asian EFL Journal, 12(2). Retrieved from http://www.asianefl-journal.com/PDF/June-2010.pdf

Nation, P. (2000). Learning vocabulary in lexical sets: Dangers and guidelines. TESOL Journal, 9(2), 6-10.

O'Dwyer, A. (2010). Tackling the real world. English Teaching Professional, 70, 46-47.

Pavlichev, A. (2002). Software review. Social Science Computer Review, 20(1), 93-98. http://dx.doi.org/10.1177/089443930202000109 
Rajaratnam, M. (1988). Primary classroom experiences. Journal of Computer Assisted Learning, 4(1), 44-53. http://dx.doi.org/10.1111/j.1365-2729.1988.tb00092.x

Senior, R. (2011). Scaffolding. English Teaching Professional, 72, 59.

Shaul, M. (2010). Teaching and testing: Bridging the gap. IATEFL Testing Evaluation and Assessment Special Interest Group, September 2010, 23-26.

Stillwell, C. (2010). Embracing the challenges of movie and television listening. In N. Ashcraft \& A. Tran (Eds.), Teaching listening: Voices from the field (pp. 99-104). Alexandria, VA: TESOL.

Ujiie, J., \& Krashen, S. D. (1996). Comic book reading, reading enjoyment, and pleasure reading among middle class and Chapter 1 middle school students. Reading Improvement, 33(1), 51-54.

Van den Branden, K. (2009). Mediating between predetermined order and chaos: The role of the teacher in task-based language education. International Journal of Applied Linguistics, 19(3), 264-285. http://dx.doi.org/10.1111/j.1473-4192.2009.00241.x

Williams, N. (1995, March-April). The comic book as course book: Why and how. Paper presented at the Annual Meeting of the Teachers of English to Speakers of Other Languages, Long Beach, California. USA.

Woodrow, L. (2006). Anxiety and speaking English as a second language. RELC Journal, 37(3), 308-328. http://dx.doi.org/10.1177/003368820607135

Yamashita, J. (2003). Processes of taking a gap-filling test: Comparison of skilled and less skilled EFL readers. Language Testing, 20(3), 267-293. http://dx.doi.org/10.1191/0265532203lt257oa

Yatvin, J. (2010, October 1). Turning schools into robot factories. The Washington Post. Retrieved from http://voices.washingtonpost.com/answer-sheet/elementary-school/-thispost-was-written.html 
Appendix A

Gap-Fill Comic

THIS COMIC WAS CREATED AT

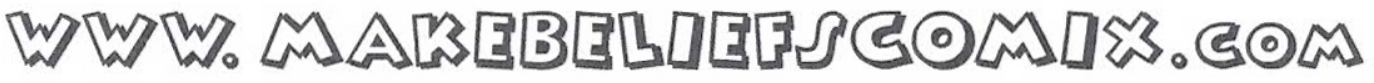

GO THERE TO CREATE YOUR OWN!

Prathom One A

Steve Graham

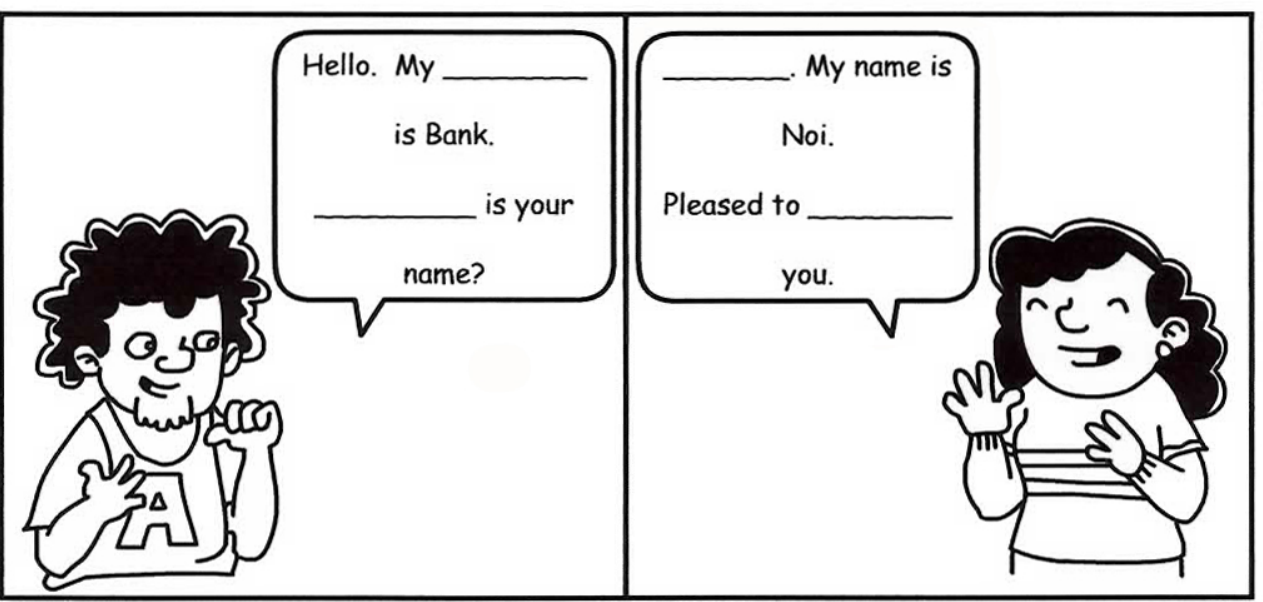

Prathom One B

Steve Graham

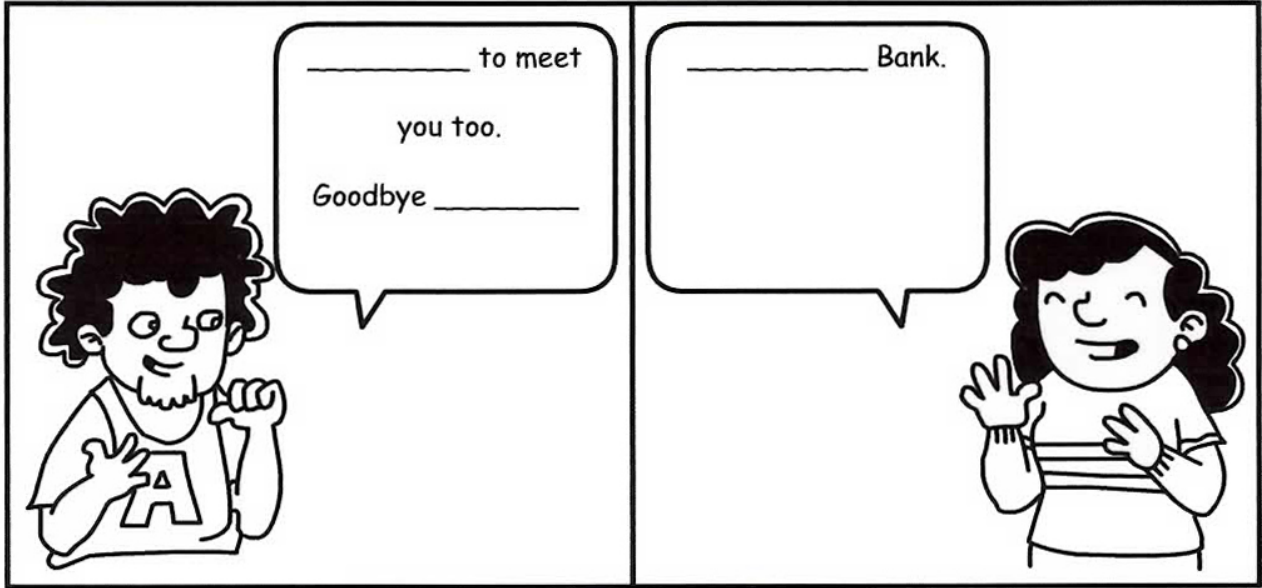

Word List

Hi name meet Noi Nice Goodbye What 